Res Publica. Revista de Historia de las Ideas Políticas ISSN: $1576-4184$

\title{
El cuerpo en los fragmentos de la novela de Nino: una interpretación en clave política*
}

\author{
María Paz López Martínez**
}

Recibido: 20 de enero de 2017 / Aceptado: 14 de julio de 2017

Resumen. Las fuentes que recogen la leyenda en torno a los reyes asirios Nino y Semíramis ha llegado hasta nosotros en diferentes soportes de épocas y contextos geográficos distintos. Contamos con materiales literarios (tradición manuscrita, óstraca y papiros) e iconográficos (inscripciones, relieves, monedas y mosaicos). En el caso de los papiros de la perdida novela de Nino, la manera en la que se representa el cuerpo de los protagonistas podría obedecer a motivos ideológicos.

Palabras clave: Nino; Semíramis; papiros literarios griegos; novela griega antigua; cuerpo; patriotismo; paideía.

\section{[en] The Body in the Fragments of Nino's Novel: an Interpretation in Political Terms}

Abstract. The legend about the Assyrian kings Nino and Semiramis has arrived to us in sources from different periods and contexts. It has been transmitted in literary (manuscript, ostraca and papyrus tradition) and iconographic (inscriptions, reliefs, coins and mosaics) supports. In the case of the papyri of the lost Ninus's novel, the way in which protagonist's bodies are represented could obey ideological reasons.

Keywords: Ninus; Semiramis; Greek literary papyri; ancient Greek novel; body; patriotism; paideía.

Sumario: 1. Introducción. 2. Los protagonistas. 3. Un hipotético origen de la leyenda. 4. Fuentes griegas del siglo I a.C.: Diodoro y los fragmentos novelescos. 5. Materiales iconográficos. 6. Interpretación de los textos. 7. La interpretación de las imágenes. 8. Conclusiones

Cómo citar: López Martínez, M. P. (2017). El cuerpo en los fragmentos de la novela de Nino: una interpretación en clave política, en Res publica 20.3, 581-602.

* Quiero agradecer las sugerencias de F. J. Campos Daroca de la Universidad de Almería y de los revisores anónimos de este artículo, que no son responsables de los errores que yo haya podido cometer.

** Universidad de Alicante

Maripaz.lopez@ua.es 


\section{Introducción}

La leyenda en torno a la pareja de los reyes asirios Nino y Semíramis constituye un ejemplo valioso en el mundo antiguo de un tema que despierta gran interés en la actualidad: la manipulación tendenciosa de la imagen corporal. Ambos son protagonistas, juntos o por separado, de una rica y compleja tradición que arranca desde muy antiguo y que ha recibido tratamiento en textos literarios en diferentes soportes (tradición manuscrita, óstraca y papiros), así como en materiales iconográficos (inscripciones, relieves, monedas y mosaicos).

\section{Los protagonistas}

La figura de Semíramis podría estar documentada en las fuentes asirias ${ }^{1}$. Su nombre parece la forma grecizada de Sammu-rāmat, el nombre de la reina asiria que fue esposa de Šamši-adad V². Al quedar viuda, siendo su hijo Adad-nirārī III todavía un menor, tuvo que ocuparse personalmente de la regencia. Hay varias inscripciones

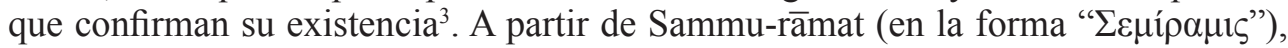
se crea un arquetipo de reinas exóticas que después se aplicó a otras célebres reinas asirias históricas como Naqi'a-Zakuûtu'.

Según la mayoría de los autores, Nino es una figura mítica ${ }^{5}$. En varias publicaciones $^{6}$, he planteado la hipótesis de que su leyenda se pudiera haber desarrollado a par-

J. Rollinger, "Semiramis", en M. Ebeling, B. Meissner, E. Weidner, W. Soden, D. Edzard, M. Streck, G. Frantz-Szabo, M. Krebernik, D. Morandi Bonacossi, J. Postgate, U. Seidl, M. Stol, G. Wilhelm, S. Ecklin, S. Pfaffinger, Reallexicon der Assyriologie und Vorderasiatischen, Berlin y Boston, De Gruyter, 2008, 11.7/8, s.v. Ya citada por Hdt. I 184 y III 155.

J. R., Novotny, "Sammu-rāmat", en H. D. Baker, The Prosopography of the Neo-Assyrian Empire, 3/1, Einsenbrauns, Helsinky 2002, pp. 1083 y ss. y S. Dalley, "The Greek Novel 'Ninus and Semiramis"”, en T. Whitmarsh y S. Thomson, The Romance Between Greece and the East, Cambridge, Cambridge University Press, 2013, pp. 117-126.

4 S. Dalley, "Semiramis in History and Legend: A case study in interpretation of an Assyrian historical tradition, with observations on archetypes in ancient historiography, on euhemerism before Euhemerus, and on the so-called Greek ethnographic style", en E. S. Guen, (ed.), Cultural borrowings and ethnic appropriations in

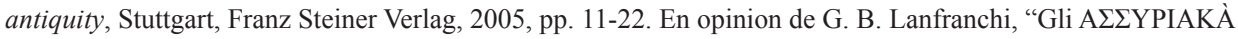
di Ctesia e la documentazione assira”, en J. Wiesehöfer, R. Rollinger y G. B. Lanfranchi (eds.), Die Welt des Ktesias: Ctesias' World, Wiesbaden, Otto Harrassowitz, 2011, pp. 175-223, aquí p. 208: “In questo caso, dunque, si debe pensare all'accettazione da parte di Ctesia di una tradizione sulla regina assira Sammu-ramat già abbondantemente consolidata nel periodo a lui precedente, e derivante in sostanza dall'elaborazione di notizie provenienti dall'ambito siro-ittita e levantino. Nè Erodoto nè Ctesia, quindi, attingono in questo caso a fonti genuinamente assire, ma ricevono e sviluppano un elemento narrativo sull'impero assiro che era stato con tutta probabilità elaborato nelle sue periferie in età arcaica".

5 W. H. Roscher, Ausfürliches Lexikon der griechischen und römischen Mythologie, Leipzig, Teubner, 3.1, 1965, pp. 369-71, s.v. Ninos.

6 M. P. López-Martínez, Fragmentos papiráceos de novela griega, Alicante, Universidad de Alicante, 1998, pp. 77-78; "Greeks, Barbarians and Strangers in Papyrological fragments of Lost Novels", en Lucentum, 17-18, 1999, pp. 221-227, aquí p. 223 y "El asirio Nino, personaje de leyenda y de novela”, en M. J. Albarrán Martínez, R. Martín Hernández e I. Pajón Leira (eds.), Estudios Papirológicos. Textos literarios y documentales del siglo IV a.C. al IV d.C., Madrid, Fundación Pastor de Estudios Clásicos, pp. 99-116. También propusieron esta identificación con otros argumentos E. A. Speiser, "Im Search of Nimrod", en Eretz Israel, 5, 1958, pp. 32-36 (este artículo fue publicado más tarde en J.J. Finkelstein y M. Greenberg (eds.), Oriental and Biblical Studies, Pensilvania, University of Pennsylvania Press, 1967, pp. 41-52) y R. Drews, "Assyria in Classical Universal 
tir de la existencia de un personaje histórico, concretamente del rey Tukultī-Ninurta I (1243-1207) ${ }^{7}$. Su vida tuvo lugar durante el período mejor documentado del reino asirio medio ${ }^{8}$ habría sido contemporánea, con todas las cautelas que se deben adoptar, a los acontecimientos que identificamos con la Guerra de Troya. Con respecto a la política interna, fundó una nueva capital, Kāl-Tukultī-Ninurta ${ }^{9}$ y llevó a cabo obras hidráulicas importantes que permitieron la redistribución del agua del Tigris. También desplegó una política exterior muy agresiva en todos los frentes -Qumanu, Urartu (Armenia) ${ }^{10}$, reino hitita y Babilonia- y fue el más célebre guerrero del siglo XIII. Las fuentes relatan que uno de sus hijos, Aššur-nasir-apli, con la colaboración de algunos cabecillas asirios, provocó una revuelta y mató a su padre en la capital que él mismo había fundado. A este rey, se le dedicó en vida una epopeya, La gesta de Tukultī-Ninurta, que conmemora su victoria sobre Kaštiliaš de Babilonia y que es la composición poética asiria más extensa de las que se nos ha conservado ${ }^{11}$.

\section{Un hipotético origen de la leyenda}

En mi opinión, la leyenda del asirio Tukultī-Ninurta I podría haber corrido una suerte paralela a la que corrió la figura de la propia reina Semíramis y del faraón egipcio Sesostris: en torno al Tukultī-Ninurta I histórico, se desarrollaría una leyenda nativa enriquecida con elementos procedentes de la tradición oral y escrita y en la que, quizás, llegaron a cristalizar episodios y rasgos que corresponden a varios reyes asirios históricos ${ }^{12}$. Se ha constatado el uso de La gesta de Tukulti-Ninurta en la educación

Histories", en Historia 14, 1965, pp. 129-142. También se plantea en las páginas introductorias a la traducción de J. Lens-Tuero, J. García González, F. J. Campos Daroca, Diodoro Sículo, Biblioteca histórica, Madrid, Ediciones Clásicas, 1995.

7 Se han propuesto otras posibles identificaciones: Tiglat-pileser I, Tiglat-pileser III, Sargon II y Senaquerib, entre otros. Para D. Lenfant, Ctésias de Cnide. La Perse. L’Inde. Autres fragments, París, Les Belles Lettres, 2004, pp. XLII-XLIV, Nino es simplemente el héroe epónimo de la ciudad de Nínive; sus conquistas, una elaboración literaria a partir de las conquistas de Ciro y su propia figura, un contrapunto a la figura de Semíramis: "la pluralité mème des modéles proposés montre que les traits de Ninos sont assez banals pour qu'il soit inutile de lui chercher un équivalent historique précis. On considérera quá au mieux, en vertu d'un processus ordinaire d'héroísation, Ninos concentre en sa seule figure les traits remarquables de divers grands rois d'Assyrie", aquí, p. XLIII. También S. Dalley, The Romance Between Greece and the East, p. 117 lo considera una figura mítica.

$8 \quad$ M. P. Streck, "Tukultī-Ninurta I", en Reallexikon der Assyriologie, 14.1-2, 2014, pp. 180-181 y 14.3-4, 2014, pp. 177-178.

9 A. Gilibert, "On Kār Tukultī-Ninurta: chronology and politics of a Middle Assyrian ville neuve”, en D. Bonatz, R. M. Czichonund y F. J. Kreppner, Fundstellen Gesammelte Schriftenzur Archäologie und Geschichte Altvorderasiensad honorem Hartmut Kühne, Wiesbaden, Otto Harrassowitz, 2008, pp. 177-188. La construcción de la nueva capital se explicaría por el deseo, por parte de Tukulti Ninurta I, de alejarse de las intrigas de la corte, algo que probablemente molestó a las elites asirias.

10 Lo cual es curioso si tenemos en cuenta el argumento de la novela de Nino donde el protagonista ataca Armenia.

11 P. Machinist, The Epic of Tukulti-Ninurta I: A Study in Middle Assyrian Literature, Ph. D. Diss., Yale University 1978 (University Microfilms International, Ann Arbor, Mi. 1992) editó el texto acadio y en "Das Tukulti-Ninurta Epos", en Reallexikon der Assyriologie, 14.3-4, 2014, pp. 180-181 presenta una síntesis del tema. B. R. Foster, Before the Muses: An Anthology of Akkadian Literature, Bethesda, CDL, 1993 (2005³) en su antología de textos acadios tradujo algunos fragmentos del poema en los que el rey habla en primera persona.

12 Nos parece muy acertado el uso del término "emblemático" por parte de J. Lens-Tuero, J. García González, F. J. Campos Daroca, op. cit., aquí p. 318, para referirse a la figura de Nino, así como la síntesis que plantea para explicar este proceso: "El primer Tukulti Ninurta fue rey de Asiria entre 1244 y 1208; el segundo reinó entre 888-884. En el Nino de Ctesias puede haber un recuerdo de estos reyes batalladores, pero Nino es básicamente 
mesopotámica del I milenio ${ }^{13}$. Esta leyenda podría haber alcanzado el primer milenio a. C. y haber llegado a oídos de escritores griegos de época clásica como Heródoto o Ctesias (con independencia de la lengua en la que ellos la recibieran), quienes finalmente incorporan en sus obras una biografía literaria del personaje bajo la forma grecizada del nombre, Nívo $\varsigma^{14}$. El anacronismo resultante entre la cronología de Tukulti Ninurta I (1244-1208 a.C.) y Sammu-rāmat (circa 810 a.C.) podría explicarse, entre otras posibles razones, por la coincidencia entre el nombre del padre de Tukulti Ninurta I (Salmanasar I) y el nombre del suegro de la propia Sammu-rāmat (Salmanasar III). El propio Diodoro afirma que fue Nino el primer rey nativo asirio del que se conserva historia y memoria ${ }^{15}$.

\section{Fuentes griegas del siglo I a.C.: Diodoro y los fragmentos novelescos}

En el siglo I a.C., Diodoro Sículo habría compuesto su Bibliotheca historica a partir de una recopilación de relatos persas incluida en la obra del griego Ctesias de $\mathrm{Cnido}^{16}$ - de la segunda mitad del siglo $\mathrm{V}$ a los primeros decenios del siglo IV a.C.-, que ejerció de médico en la corte persa de Artajerjes $\mathrm{II}^{17}$. La obra de Ctesias,

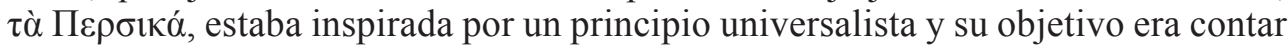
la historia de los imperios de Asia desde sus orígenes hasta el rey persa Artajerjes II -398/397 a.C.-. El texto completo no se ha conservado, pero nos han llegado

una figura emblemáticas. Entre sus funciones está la de ser personaje etiológico de la ciudad de Nino". F. Parreu Alasà, Diodoro de Sicilia. Biblioteca Histórica, Libros I-II, Madrid, Ediciones Clásicas, 2001, pp. $92-93$ equipara a Nino con "personajes míticos de la talla de un Sesoosis, un Ramsés o un Alejandro... parece un conglomerado de diversos reyes asirios importantes del imperio nuevo: Tiglatpileser IV, Sargón II, Senaquerib y Asarhadón, de un modo muy parecido a como los Sesostris y Amenemhets de Egipto dan origen a un mítico Sesoosis".

13 D. M. Carr, The Formation of the Hebrew Bible: A New Reconstruction, Oxford y Nueva York, Oxford University Press, 2011, p. 312.

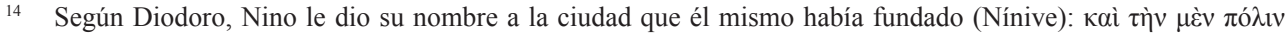

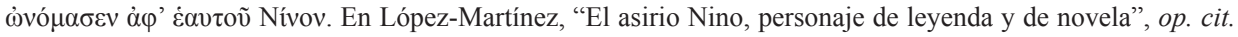
he planteado un posible origen del antropónimo Nívoç. Lanfranchi, op.cit., pp. 208-209: "I nomi di Ninos e di Ninyas, invece, costituiscono un problema di difficile soluzione... naturalmente, la tesi della derivazione diretta dal nome di Ninive resta comunque valida... ma tutto ciò deve restare nel campo delle mere ipotesi per mancanza di documentazione al riguardo".

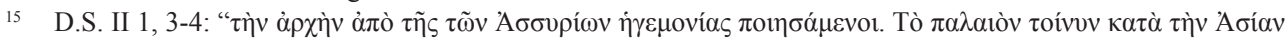

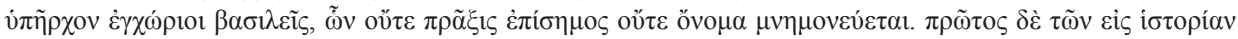

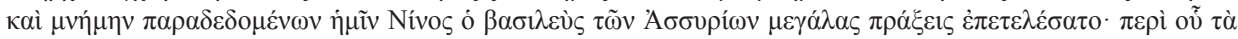

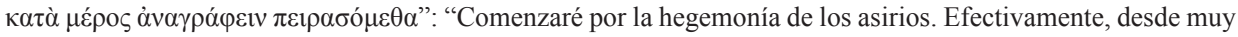
antiguo, hubo en Asia reyes nativos de los que no se recuerda ni hazaña alguna ni nombre. El primero de los que nos ha llegado su historia y su memoria es Nino, rey de los asirios, que llevó a cabo grandes hazañas y sobre quien vamos a componer un relato detallado".

16 Es muy ilustrativa la indicación del Lenfant, op. cit., p. VIII: "Il était donc de la génération suivant celle d'Herodote et fut un contemporain d'Hippocrate, de dix a vingt ans son ainé".

17 A lo largo de su larga historia, el imperio persa había acumulado una ingente cantidad de documentación tanto escrita (inscripciones reales, tratados, cartas, documentos administrativos y económicos, así como obras literarias y científicas) como de tipo monumental. En época de Heródoto o de Ctesias, todos estos materiales ya se habrían transformado en un conjunto descontextualizado e inconexo, por lo que distinguir lo asirio de lo no asirio constituiría un auténtico reto. Cf. "Gli A $\Sigma \Sigma$ YPIAKÀ di Ctesia e la documentazione assira". Ctesias asegura haberse basado en la consulta de pergaminos reales persas: "oṽ (F. Jacoby (ed.), Die Fragmente der griechischen Historiker, Leiden, Brill, (1923-1958 (repr. 1954-1969), F 3C $(=688.5 .22)$. 
fragmentos. Ésta abarcaría la historia de los reinos asirios, medas y persas, siendo el propio Diodoro quien reconoce abiertamente la dependencia de su obra con respecto a la del médico de $\mathrm{Cnido}^{18}$. Así también es probable que el anónimo autor de una novela perdida protagonizada por el rey asirio Nino y escrita por estas mismas fechas -mediados del siglo I a.C.- se basara en la obra Ctesias ${ }^{19}$. Ambos relatos (el histórico y el novelesco) ofrecen dos planteamientos completamente distintos hasta el punto de que da la impresión de que el relato novelesco se ha construido contra el historiográfico.

El mismo motivo fue utilizado por otros autores, lo que demuestra el interés que despertó la pareja de reyes orientales entre el público grecorromano de diferentes épocas y latitudes ${ }^{20}$. Es incluso probable que se escribiera una novela también perdida cuya protagonista fuera la reina asiria y de la que nos puede haber llegado un fragmento papiráceo recientemente publicado en la colección de Oxirrinco, el $P$. Oxy. $2564^{21}$.

La descripción que hace Diodoro de Nino responde al arquetipo de gran rey fundador y conquistador universal, rasgos que encontramos también en otros líderes de grandes potencias antiguas, como Sesostris en Egipto o Alejandro en Grecia, prota-

18 Sobre Asiria en la historiografía griega: R. Drews, "Assyria in Classical Universal Histories", en Historia 14, 1965, pp. 129-142 y G. B. Lanfranchi, op.cit., pp. 175-223, entre otros.

19 He atribuido al siglo I a. C. la composición de la novela, por razones que explico en publicaciones todavía en preparación o en prensa. Otros, como S. Tilg, Chariton of Aphrodisias and the invention of the Greek Love Novel, Oxford, Oxford University Press, 2010, quien se basa en datos proporcionados en estudios anteriores de otros autores, proponen que la novela de Nino se habría escrito en torno al 66-68 d. C. en Afrodisias, después de que Caritón escribiera sus relatos sobre Calírroe, datación que es compartida por algunos otros expertos en el tema.

20 E. F. Weidner, en Paulys Realencyclopädie der classischen Altertumswissenschaft, Metzler, Stuttgart, 17.1, 1936, cols. 634-643, s.v. Ninos (3); T. Lenschau, en ibidem, 7, 1940, cols. 1204-1212, s.v. Semiramis; C. F. Lehmann-Haupt, en W. H. Roscher, op.cit., 4.1, 1965, 678-702, s.v. Semiramis y E. Mignona, "Semiramide e Nino", en A. Stramaglia, 'E $\omega \omega \varsigma$. Antike trame greche d'amore, Bari, Le Rane, 2000, pp. 322-326 para las fuentes literarias y los testimonios del mito. También en R. Kussl, Papyrusfragmente griechischer Romane. Ausgewählte Untersuchungen, Tubinga, Gunter Narr, 1991, pp. 13-96 y R. Kussl, "Ninos-Roman”, en Papyrologica Lupiensia 5, 1997, pp. 141-204. Sobre la figura de Semíramis concretamente: W. Eilers, Semiramis: Entstehung und Nachhall einer altorientalischen Sage, Viena, H. Böhlaus Nachf, 1971; Pettinato, Semiramide, Milán, Rusconi Libri, 1985 y M. G. Capomacchia, Semiramis: una femminilità ribaltata, Roma, L'Erma di Bretschneider, 1986. El propio Diodoro recoge, en forma de rumores, otras versiones de la leyenda referidas por Ateneo (D.S. II.20.35): Semíramis era una hermosa hetera de la que se enamoró el rey. Al principio, se enfrentó al rechazo de la corte pero, una vez legitimado su estatus como esposa, convenció a su esposo, el rey, para ocupar ella el poder durante cinco días. Es entonces cuando Semíramis aprovechó para celebrar un espléndido banquete durante el cual aprovechó para agasajar a los miembros de la nobleza y del ejército, encerrar al rey y proclamarse soberana, cargo que Semíramis ocupó hasta su muerte a edad avanzada. E. Murphy, The Antiquities of Asia. A Translation with Notes of Book II of the Library of History of Diodorus Siculus, New Brunswick-Oxford, Routledge, 1989, p. 27, n. 59 comenta en nota que Eliano en V.H. 7.1 también da cuenta de noticias muy similares. Algunas fuentes hablaron de incesto y otras, de un suicidio tras la muerte del caballo que tenía por amante, Higino, Fabula 243.8 .

21 Y. Trnka-Amrhein, “2564. A Queen and her pyramids”, en J. H. Brusuelas y C. Mecariello (eds.), The Oxyrhynchus Papyri, vol. 84, pp. 40-46, lámina I. 
gonistas, a su vez, de sendas novelas griegas ${ }^{22}$. En la biografía de Nino, Diodoro ${ }^{23}$ presenta de manera muy sintética sus éxitos en política exterior: alianza con el rey de Arabia, campañas contra Babilonia, Armenia, Media, Egipto, Fenicia y casi todo el resto de pueblos entre Asia Menor y Asia, entre el Nilo y el Tanais, a excepción de India y la Bactriana. Es precisamente, su primer fracaso en la Bactriana lo que provoca la vuelva a su patria donde fundará una ciudad amurallada e iniciará una importante actividad constructora. Emprende, de nuevo, un segundo ataque a este mismo territorio donde se enamora de la bella e inteligente esposa de su subordinado. En un rápido relato, Diodoro refiere el final de la biografía de Nino: la boda con Semíramis, el nacimiento de su hijo Ninias, su muerte y la construcción de un cenotafio en su honor dedicado por su viuda, quien, a partir de ese momento, será considerada reina de Asiria.

Después de la fundación de esta ciudad (Nínive) ${ }^{24}$, Nino emprendió una campaña militar contra la Bactriana, en la cual se casó con Semíramis, la más famosa de todas las mujeres que conocemos; obligado es hablar de ella y de cómo alcanzó semejante categoría partiendo de un origen tan humilde ${ }^{25}$.

Es Semíramis, en realidad, la verdadera protagonista del libro segundo de la Biblioteca de Diodoro. Fue hija de Derceto de Ascalón ${ }^{26}$. Su madre ${ }^{27}$, atormenta-

22 M. Braun, History and Romance in Graeco-Oriental Literature, Blackwell, Oxford 1938, reimpresión Nueva York-Londres 198 fue un precursor de la idea. De la novela, también perdida, protagonizada por el faraón Sesostris nos han llegado cinco fragmentos, dos de ellos de reciente publicación. A los ya conocidos $P$. $O x y$. 2466, P. Oxy. 3319 y P. Oxy. 1826 editados en S.A. Stephens y J. J. Winkler, (eds.), Ancient Greek Novels. The Fragments, Princeton, Princeton University Press, 1995, pp. 246-66 y M. P. López Martínez, Fragmentos papiráceos de novela griega, Alicante, Universidad de Alicante (1998a), (edición en mic: Alicante 1994), pp. $357-$ 75, se añaden los fragmentos P. Oxy. 5262 y 5263 editados por Y. Trnka-Amrhein, "5262-5263.Sesonchosis", "5262.Sesonchosis (more of XXVII. 2466” y "5263.Sesonchosis" en J. H. Brusuelas y C. Mecariello (eds.), The Oxyrhynchus Papyri, vol. 84, pp. 19-21, 21-24 y 25-40, láminas IV y V. De la Novela de Alejandro, hay muchos papiros, entre los que cabe destacar: P. Berol. inv. 21266v, P. Hal. inv. 31, P. Mich. XVIII 761, PSI VII 743 y P. Berol. inv. 13044. Entre la numerosa bibliografía, nos limitamos aquí a citar la edición de G. Kroll, Historia Alexandri Magni (Pseudo-Callisthenes) volume I. Recensio vetusta, Berlín, Weidmann, 1926 y la monografía de C. Jouanno, Naissance et métamorphoses du Roman d'Alexandre. Domaine grec, París, CNRS Editions, 2002 , entre otros.

23 El relato de los reyes asirios corresponde a los capítulos II 1.4-II 28.8 de la obra de Diodoro. Remitimos a las ediciones y traducciones disponibles para su consulta. Las traducciones son mías.

24 El nombre acadio de la ciudad es Ninua.

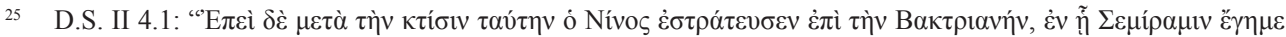

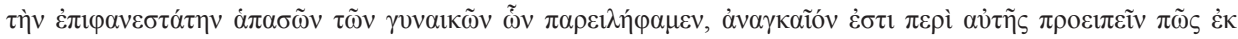

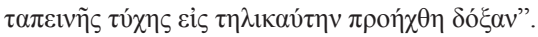

26 Atargatis. En época helenística se conoce a Astarté como diosa siria. Hdt. I 105 indica la existencia en la zona -Ascalón está en la costa de Palestina, cerca de Gaza- de un santuario de Afrodita (el equivalente griego de la Astarté fenicia). En la actualidad es Ashqelon en Israel. Es curioso que las excavaciones hayan confirmado la existencia de un estanque en el sitio de Ascalón, vid. D. Lenfant, Ctésias de Cnide. La Perse. L'Inde. Autres fragments, París, Les Belles Lettres, 2004, p. 236.

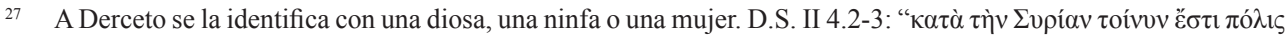

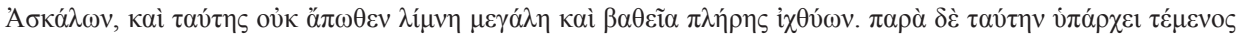

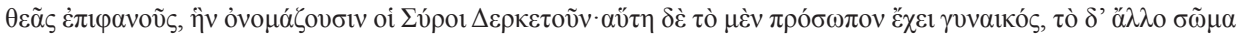

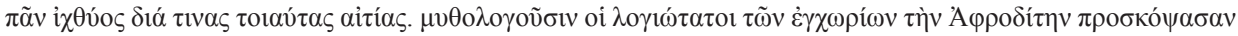

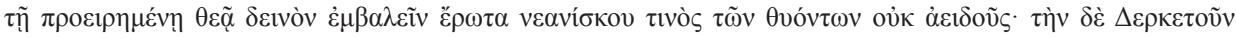

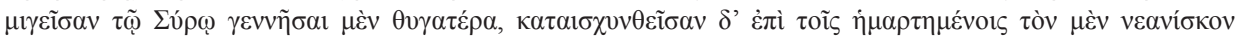

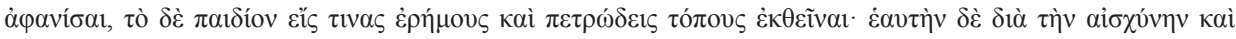


da por sus sentimientos hacia el atractivo mortal con quien había concebido a su hija ${ }^{28}$, se lanzó a un lago metamorfoseada en pez y abandonó a Semíramis, siendo ésta todavía una recién nacida. La criatura consiguió salir adelante gracias a los cuidados de unas palomas y fue hallada más tarde por unos pastores, quienes la entregaron al vigilante de los rebaños del rey. Simas adoptó a la niña y le puso un nombre parlante, "Semíramis", que en lengua siria significaba "paloma", según Diodoro $^{29}$ :

En torno al lugar donde quedó abandonada la criatura, como había un montón de palomas anidando, éstas alimentaron a la niña de manera prodigiosa y milagrosa: Así, unas mantenían caliente el cuerpo de la criatura, cobijándolo por todas partes con las alas, mientras las otras, desde los establos próximos, vigilaban cuando los vaqueros y los demás pastores se alejaban y, trayéndole leche en el pico y dejándosela gotear entre los labios, la alimentaban. Cuando llegó al año y necesitaba alimento sólido, las palomas picoteando en los quesos, le proporcionaban alimento suficiente. Al volver los pastores y observar los quesos mordisqueados, se admiraron del prodigio. Así que vigilando y averiguando la causa, encontraron a la niña, de una belleza sin par. Así que, inmediatamente, la llevaron al establo para entregársela al vigilante de los rebaños del rey, de nombre Simas. Este, como no tenía hijos, alimentó a la niña, como si fuera su hija con toda clase de cuidados y le puso por nombre Semíramis, que en lengua siria es llamada así por las palomas, a las que, a partir de aquellos días, todos los habitantes de Siria veneran como a diosas. Más o menos así es lo que se cuenta del nacimiento de Semíramis ${ }^{30}$.

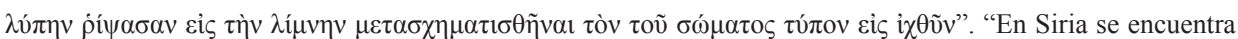
la ciudad de Ascalón, y no lejos de ella, un lago lleno de peces. Junto a este, un santuario de la afamada diosa a quien los sirios llaman Derceto. Tiene rostro de mujer, pero todo el resto del cuerpo es de pez por la siguiente razón: cuentan los más entendidos de los paisanos que Afrodita ofendida por la diosa a la que nos acabamos de referir inspiró en ella una poderosa pasión hacia un joven de los que celebraban sacrificios en su honor y que era de aspecto desagradable. Después de que Derceto se unió al sirio, concibió una hija, pero avergonzada ella por sus faltas, hizo desaparecer al joven y colocó a la recién nacida en un lugar solitario y rocoso. Ella, avergonzada ante su propio impudor y dolor, se lanzó al lago metamorfoseando la forma de su cuerpo en la de un pez".

28 En un escolio a la Ilíada se dice que el joven se llamaba Kaystros y que era hijo de la amazona Pentesilea.

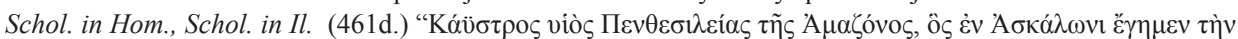

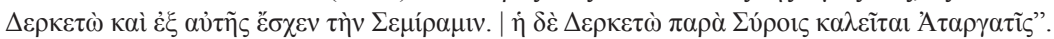

29 En arcadio, paloma es summatum, Lenfant, ibidem, p. 236. Se trata de un mito de carácter etiológico para explicar la veneración que los sirios rendían a los peces y a las palomas, vid. Lenfant, ibidem, p. XLV. Sobre el nombre de "Semíramis", M. G. Capomacchia, op. cit. p. 22, n. 21. Sobre la secuencia, exposición de la criatura, cuidados de un animal, adopción, vid. Hdt., II 2.2 y Longus, I 2-6, entre otros.

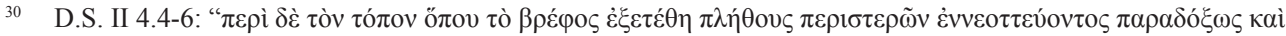

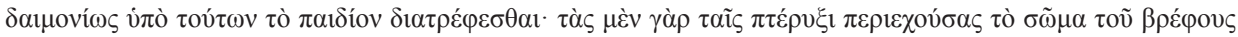

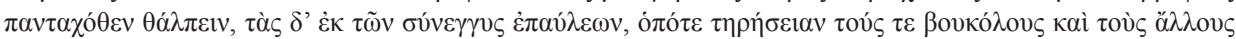

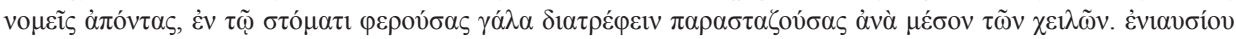

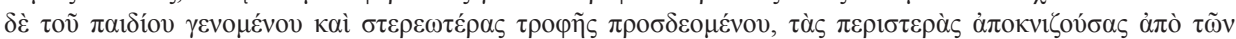
$\tau$

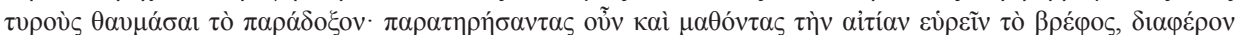

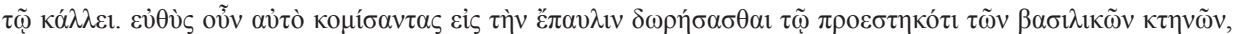

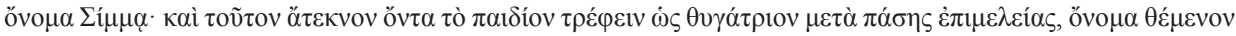

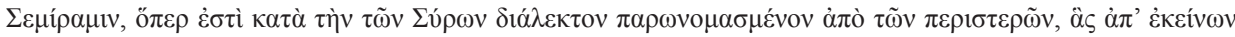

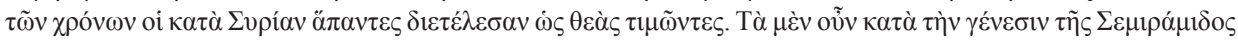

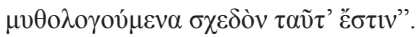


Semíramis crece y se convierte en una bella e inteligente joven de la que se enamora Ones, enviado por el rey (Nino) a la casa del padre de la muchacha en visita oficial. Impresionado por la belleza de Semíramis, Ones la pide en matrimonio y fruto de estas nupcias nacen dos hijos, Hiapates e Hidaspes.

Cuando llegó ya a la edad de casarse y siendo de una belleza muy superior a las demás muchachas, un general subordinado fue enviado de parte del rey para supervisar los rebaños reales. Este se llamaba Ones, era el primer consejero del rey y había sido nombrado general de toda Siria. Se hospedó en casa de Simas y, cuando vio a Semíramis, quedó cautivado por su belleza. Por eso, pidiéndole a Simas que le concediera la muchacha para un matrimonio legítimo, la llevó a Nínive, se casaron y tuvieron dos hijos: Hiapates e Hidaspes. Como Semíramis reunía también otras cualidades que acompañan a la belleza de aspecto, sucedía que su marido estaba completamente subyugado por ella, no hacía nada sin consultarle su opinión y tenía éxito en todas sus empresas ${ }^{31}$.

Tan subyugado estaba Ones a la voluntad y opinión de su esposa que, durante la prolongada e infructuosa campaña contra la Bactriana ${ }^{32}$, a la que Ones acude acompañando al rey, la hace presentarse en el frente de batalla. Antes de emprender el viaje, la propia Semíramis se tejió una túnica con la que estar cómoda y ocultar sus encantos femeninos ${ }^{33}$. Dicho atuendo hasta el punto de que más tarde medos y persas lo lucieron en $\mathrm{Asia}^{34}$. Volveremos a este episodio del relato que nos parece importante ${ }^{35}$.

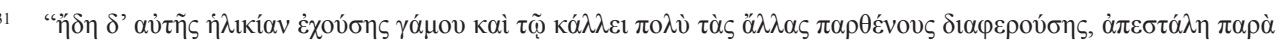

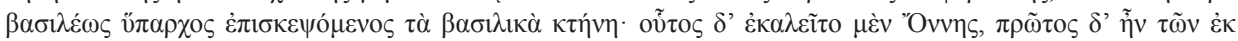

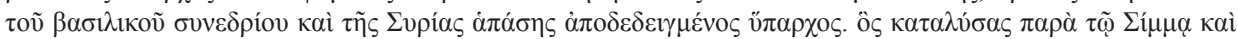

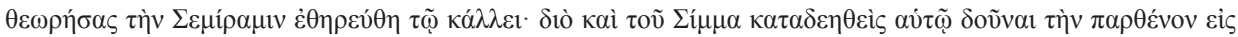

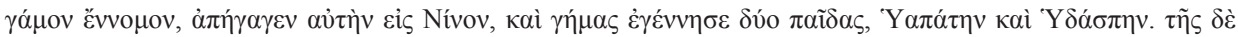

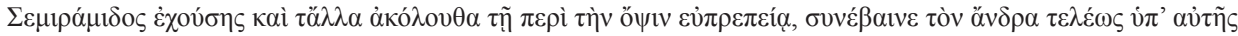

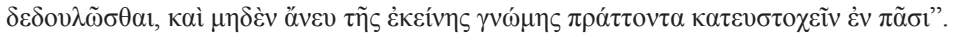

32 (Balkh), al norte del Afganistán actual, en Asia central.

33 Helánico, junto con Heródoto, autor que precede a Ctesias en el estudio de la historia de Persia, ya sostuvo que Atosa había sido la primera mujer que había llevado tiara y pantalones para esconder su femineidad. Anon. De mul. 7: "Atosa: Helánico dice que esta, criada por su padre como un varón, recibió el reino. Ocultando su mente femenina, fue la primera en lucir la tiara y también en llevar pantalones, por primera vez, se encontró con el favor de los eunucos y hacía consultas en los libros. Sometiendo muchos pueblos, llegó a ser la más guerrera

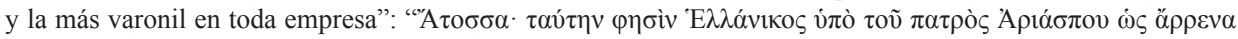

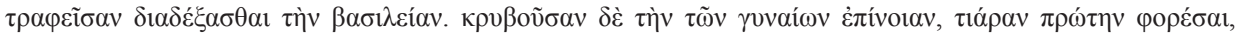

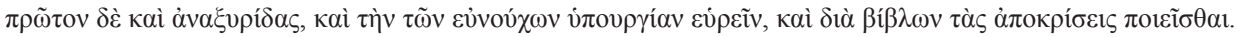

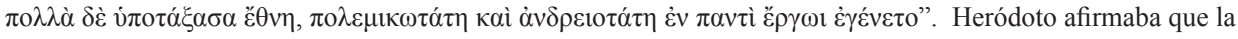
tiara y los pantalones eran una indumentaria originariamente meda, Hdt. VII 61.

34 De esta manera tan sutil sugiere Diodoro que los persas llevan ropa de mujer, un manto que les cubre el cuerpo entero. Por su parte, los persas opinaban que los griegos vestían como los salvajes. Cf. E. Murphy, op.cit., p. 9, n. 26.

35 Se trata de un ejemplo que ilustra bastante bien la metodología histórica de Ctesias, en ocasiones, injustificadamente denostada. Cf. G. B. Lanfranchi, op. cit., p. 201: "Anche in questo caso, dunque, Ctesia opta per un trasferimento al mondo assiro dell' invenzione e dell' adozione di uno specifico elemento di cui si «deve» ricercare un' origine nel passato antico: in questo caso, toglie ai Medi quella primazia che spettava loro secondo Erodoto e più specificamente secondo Ellanico. In sostanza, per Ctesia il passato più remoto, quello a cui vanno ascritte le opere fondanti della realtà contemporanea, é l'impero assiro; e dunque sia il ruolo di Babilonia sia quello della Media ne escono in qualche modo sminuiti". 
Ya en la Bactriana, Semíramis diseña una estrategia militar con la que el rey Nino resulta vencedor. Entonces, éste se fija en ella, sucumbe a sus encantos y provoca (involuntariamente) el suicidio del marido de Semíramis. El relato de Diodoro es muy lacónico: Semíramis vuelve a enviudar por segunda vez y, a partir de ese momento, comienza una nueva vida para ella.

No vamos a resumir aquí el resto de los avatares que se producen, a continuación, en la vida de Semíramis: En el relato de Diodoro se suceden campañas militares y gestas que superan a las de cualquier gran héroe nacional de un pueblo antiguo. Sin embargo, su final es triste: consiste en la conspiración de su propio hijo que provoca su muerte metamorfoseada en paloma. Semíramis ha vivido sesenta y dos años y ha reinado cuarenta y dos.

Su hijo Ninias heredará el trono, pero no las cualidades militares y la ambición de su madre: sus días transcurren encerrado dentro del palacio junto a concubinas y eunucos, entregado al placer y a la molicie, hasta el punto de representar el comienzo de la decadencia del imperio asirio ${ }^{36}$.

Por estas mismas fechas, un autor anónimo compondría una novela perdida conocida actualmente como Novela de Nino de la que se conservan cuatro fragmentos, que corresponden a dos papiros de entre los siglos I a.C.-I d.C. y que son los más antiguos testimonios del último género literario nacido en Grecia ${ }^{37}$. Además de los papiros, contamos con un óstrakon de finales del siglo I-comienzos del II d.C., que presenta problemas de lectura y que podría tener carácter escolar y es posible que se trate una breve composición, a modo de práctica, como la redacción de una carta inspirada en el argumento y los personajes de la novela ${ }^{38}$.

Teniendo en cuenta el contenido de los fragmentos, los argumentos de las otras novelas conservadas y los estudios publicados sobre el tema, he planteado un posible argumento de la novela en los términos siguientes: el joven príncipe asirio crece en palacio junto a su padre -cuyo nombre no conocemos- y su madre, Tambe. Su infancia transcurre en estrecho contacto con su tía Dercia y su prima-cuyo nombre tampoco aparece en los papiros, aunque suponemos que es Semíramis-. Como heredero del trono, recibe una esmerada educación. Pronto los jóvenes primos descubren su mutuo amor y se comprometen, pero se mantienen castos. Nino tiene que afrontar sus primeras empresas militares, primero por tierra contra Armenia (acudiendo solo al campo de batalla, pero todavía en vida de su padre).

Nino demuestra la exquisita educación que ha recibido, una $\pi \alpha 1 \delta \varepsilon i ́ \alpha$ a la griega: sobresaliente tanto en los lances retóricos como bélicos. Tiene 17 años y prisa por casarse, reclama ante su tía la mano de su prima con un brillante discurso:

36 G. B. Lanfranchi, op. cit. 2011, pp. 214-217 relaciona el comportamiento de Ninias con rituales propios del culto a la diosa Istar, entre ellos, vestir con ropa de mujer. Este dato confirma la especial devoción de los reyes asirios prestaron a este culto. Este detalle demostraría el manejo de fuentes propiamente asirias por parte de Ctesias.

37 Disponemos de varias ediciones, traducciones y estudios: R. Kussl, Papyrusfragmente griechischer Romane. Ausgewählte Untersuchungen y "Ninos-Roman"; Stephens y Winckler, op. cit., 1995, pp. 23-71 y M. P. López-Martínez, op. cit. 1998, 37-80. El papiro más extenso está compuesto de dos fragmentos (A y B). Mantengo la ordenación BA, como en mi edición de 1995, frente a la ordenación AB que presentan la mayoría de los editores.

38 Cf. A. Stramaglia, "Fra «consumo» e «impegno»: usi didattici della narrativa nel mondo antico" y "Apppendice. Riedizione di OEdfu 306", en O. Pecere y A. Stramaglia (eds.), La letteratura di consumo nel mondo greco-latino. Atti del convegno internazionale (Cassino, 14-17 settembre 1994), Cassino, Università degli Studi di Cassino, 1996, pp. 97-166 y M. P. López-Martínez, ibidem, pp.68-69. 
Oh madre, tras mantener mi juramento, vengo para verte y para abrazar a mi dulcísima prima, ique lo sepan los dioses, en primer lugar, como seguro que ya lo saben y yo lo voy a demostrar enseguida con el discurso que voy a pronunciar ahora. Después de recorrer tanta tierra y adueñarme de tantos pueblos, o bien ganados con la lanza, o bien que me sirven y se prosternan ante mí por el poder de mi padre, podría haberme colmado hasta la saciedad de todo tipo de placeres y, si lo hubiera hecho, quizás tendría menos deseo de mi prima, pero, como he vuelto casto, ahora estoy vencido por el dios y por la edad. Tengo diecisiete años, como sabes, y ya hace uno que se me cuenta entre los hombres, pero hasta ahora no soy más que un niño inocente y, si no conociera a Afrodita, sería feliz por mi firmeza. Pero ahora, cautivo de vuestra hija, no de un modo vergonzoso, sino con vuestro consentimiento, ¿hasta cuándo negaré que lo soy? Es evidente que los varones de mi edad están en condiciones de casarse, ¿cuántos se han guardado castos hasta los quince años? Me perjudica una ley no escrita, sancionada, además, por una necia costumbre, puesto que, entre nosotros, las vírgenes, en su mayoría, se casan a los quince años y el hecho de que la naturaleza es la mejor ley de tales uniones, ¿quién, pensando sensatamente, podría negarlo? A los catorce años, se quedan encinta mujeres y algunas, ipor Zeus!, incluso dan a luz, en cambio, ¿tu hija no se va a casar? Que esperemos dos años, podrías decir, lo aceptaremos, madre, si también la Fortuna espera. Pero soy un varón mortal que está comprometido con una doncella mortal y no estoy sujeto sólo a los azares corrientes, me refiero a las enfermedades y al azar que muchas veces también arrastra a quienes están tranquilos en el hogar familiar, sino que a mí me esperan viajes por mar y guerra tras guerra y ni soy un cobarde ni alego como pretexto temor, como aliado de mi seguridad, sino, como sabes, para no ponerme pesado repitiéndolo. Que apresure (la boda) el reino, que la apresure nuestra pasión, que la apresure lo inestable e incierto de los tiempos que me esperan y que la adelante y acelere el hecho de ser ambos hijos únicos, para que, si la Fortuna, por otra parte, planea alguna desgracia con respecto a nosotros, os dejemos algo en prenda. Dirás quizás que hablo de esto con descaro, pero yo sería un descarado si lo intentara a escondidas, si arrebatara un placer robado e hiciera cómplices de mi pasión a la noche, la embriaguez, a un criado o a la nodriza, pero no soy un descarado por hablar con una madre sobre las ansiadas bodas de su hija, por reclamar lo que me diste y por pedirte que no aplaces los deseos comunes a la familia y a todo el reino hasta una ocasión tal que ya no existirá para nosotros ${ }^{39}$.

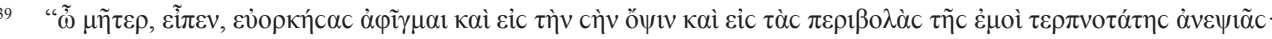

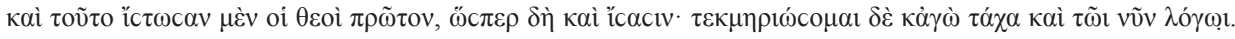

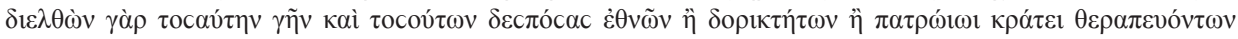

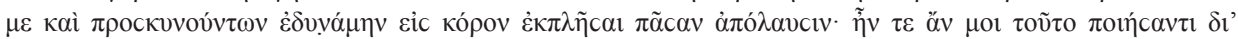

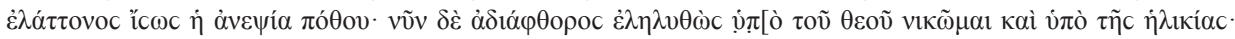

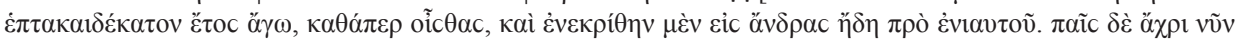

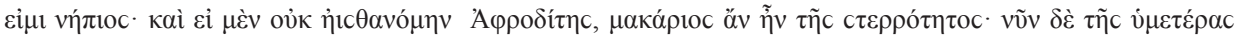

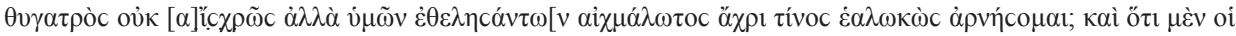

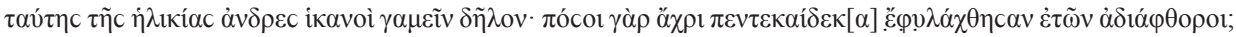

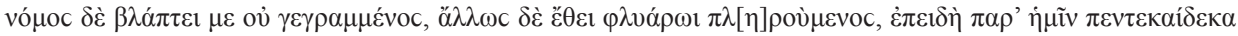

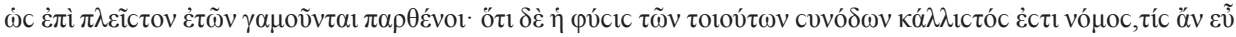

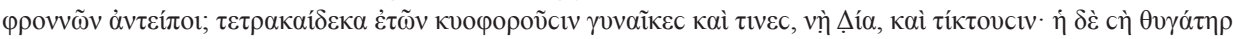

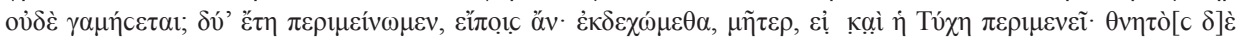


Sin embargo, la muchacha incapaz de pronunciar una sola palabra se avergüenza de sus sentimientos, por encontrarlos indecorosos y se queda completamente paralizada.

La muchacha, en el mismo estado emocional, no tenía la misma libertad de palabra ante Tambe, pues ella, una doncella que vivía dentro del gineceo, no encontraba convenientes sus propias palabras. En cuanto pedía una oportunidad, se ponía a llorar y quería decir algo, pero antes de empezar, desistía. Enseguida, mostrando una intención espontánea de hablar, abría los labios y levantaba la vista, como si fuera a decir algo, pero al final no decía nada, fluían sus lágrimas y enrojecían sus mejillas por vergüenza de lo que iba a decir... Un nuevo intento de hablar, palidecía a causa del temor. Se debatía entre la esperanza, el deseo, el miedo y la vergüenza. Mientras su pasión aumentaba, le faltaba la resolución... después de mucho... Tambe, enjugándole las lágrimas con sus manos, le pidió que se animara y que le dijera lo que quisiera pero, como no decía nada, sino que la muchacha seguía abrumada por los mismos males, le dijo: "Mejor que cualquier discurso, me habla tu silencio. No vayas a hacerle reproches a mi hijo, pues ni ha sido un desvergonzado ni, al volver con nosotros, envalentonado por sus éxitos y trofeos, se ha comportado contigo como un soldado ebrio. Quizás, si esto hubiera ocurrido, no habrías estado callada, pero lenta es la ley con respecto a las bodas... y mi hijo tiene prisa, pero ni por eso... por lo que lloras, te tienes que sentir forzada". Y mientras sonreía, la abrazaba y la besaba... hablar, ni siquiera entonces la muchacha se atrevió y apoyando contra su pecho el corazón de Semíramis que latía fuertemente y besándola con mucha dulzura, creyó que sólo con las lágrimas antes y con la alegría de ese momento, se expresaba lo que quería ${ }^{40}$.

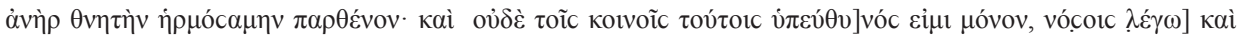

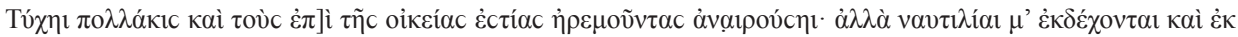

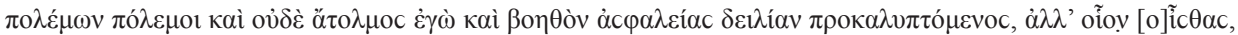

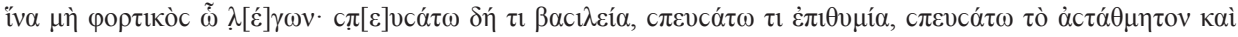

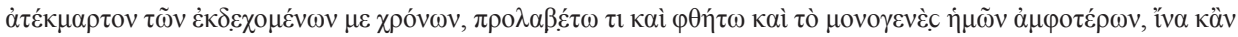

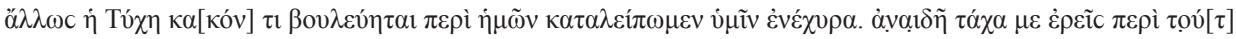

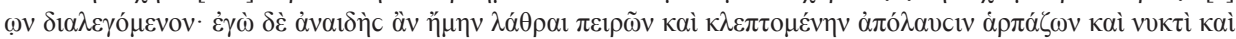

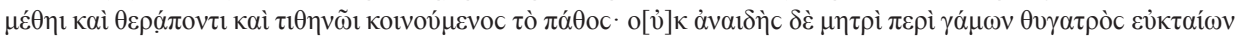

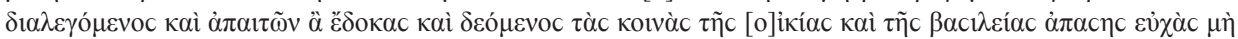

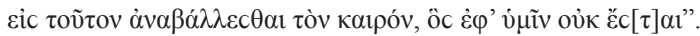

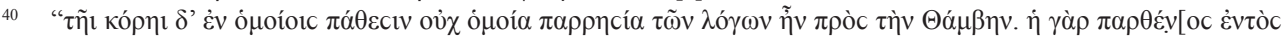

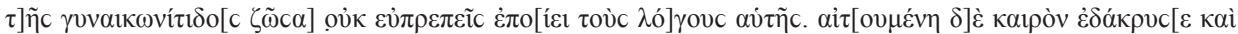

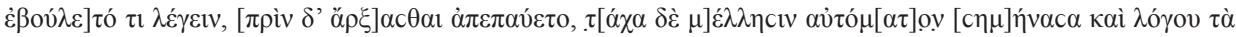

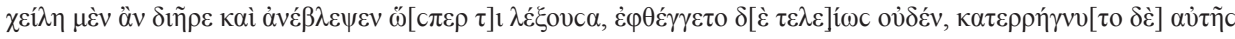

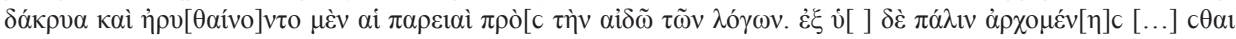

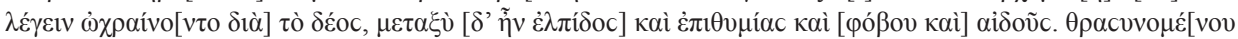

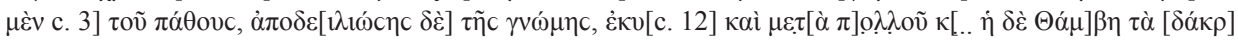

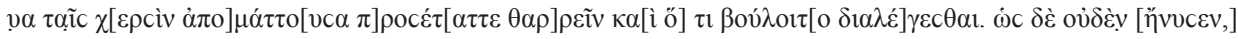

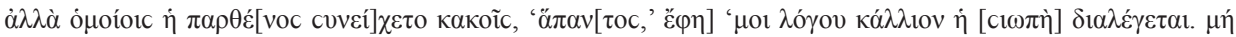

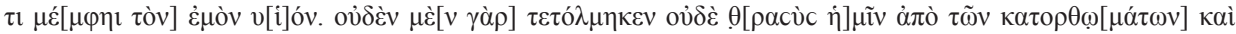

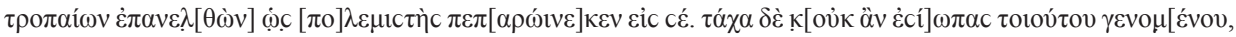

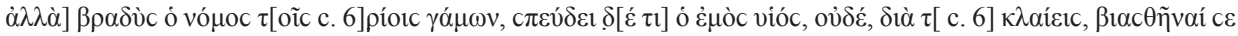

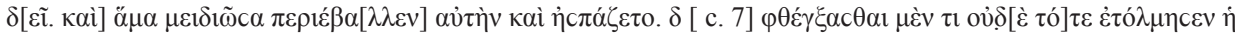

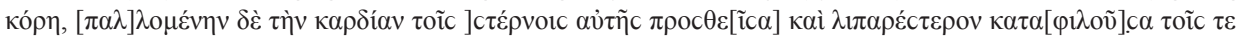

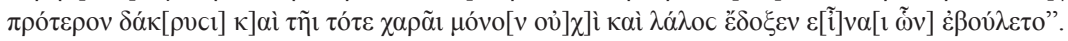


Se suceden probablemente otros viajes y nuevas campañas militares. El segundo papiro nos presenta a Nino de travesía por mar, llegando a la Cólquide. Es incierto si Nino ya está casado en este punto del relato, tampoco sabemos si lo acompaña su prima. En caso de viajar solo, nos preguntamos qué ocurre con su prometida: ¿Se ha quedado esperándolo en palacio como Penélope? ¿Ha emprendido sus propios viajes y está viviendo sola sus propias aventuras? Nino, abatido y rodeado de su tripulación, naufraga en una costa, situada en el límite del mundo conocido, en la orilla del río Hippos, cerca de Fasis. Aquí se interrumpe el papiro y los fragmentos con los que contamos de la novela.

\section{Materiales iconográficos}

En varias ciudades de Asia Menor, contamos con una serie de testimonios de finales del siglo I d.C. - concretamente del 90 d.C.- en los que nuestros protagonistas aparecen representados como héroes fundadores de varias ciudades minorasiáticas $^{41}$.

El más importante es el relieve que adorna la basílica de Afrodisias en Caria.

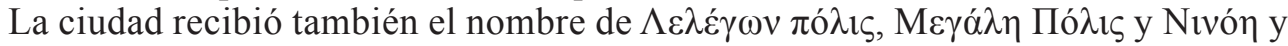
en ella se rendía culto a Zeus Nineudios. La ciudad también podría considerarse vinculada a Semíramis porque ésta era descendiente de Afrodita y dicha diosa también recibía culto en la ciudad. En una de las partes del relieve, aparece repre-

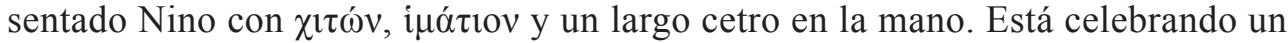
sacrificio o una libación junto a un altar sobre el que descansa un águila. También hay un árbol seco con tres largas ramas y, junto a Nino, una figura masculina vestida con la clámide deposita ofrendas en un altar más pequeño. En otro relieve, Semíramis, velada y vestida con peplo e i $\mu \alpha ́$ ctov, apoyada en una larga vara (quizás un tirso), sostiene una rama frondosa en la otra mano. En el centro de la escena hay un altar y, en el otro lado, está representada una figura masculina que parece un miembro de la Curia. En el 250 d.C. se inscribieron los nombres de los personajes, lo que indica que por esas fechas -mediados del siglo III d.C.- la mayoría de la población ya no los reconocía a simple vista. Tanto Nino como Semíramis presentan el aspecto noble y respetable de quien encarna las virtudes cívicas.

Otro testimonio importante es un conjunto de monedas del siglo II-III d.C. que proceden de la ciudad de Aninetta, en la frontera entre Caria y Lidia, donde aparece Nino representado como fundador de la ciudad. Algo más al norte, en Thyatira, en Lidia, también encontramos a Semíramis como ė

\footnotetext{
A. Chaniotis, "Von Erlebnis zum Mythos: Identitätskonstruktionen im Kaiserzeitlichen Aphrodisias", en E. Schwertheim y E. Winter (eds.), Stadt und Stadtentwicklung in Kleinasien, Bonn, Rudolf Habelt, 2003, pp. 6984 y B. E. Borg (ed.), Paideia: The World of the Second Sophistic y Identities and empire: Local mythology and the self-representation of Aphrodisias, Berlin-Boston, De Gruyter, 2004, y B. Yildirim, "Identities and empire: Local mythology and the self-representation of Aphrodisias", en B. E. Borg (ed.), op. cit., pp. 23-52, han estudiado y descrito con mucho detalle todos estos materiales. S. Tilg, op.cit., pp. 118-122 y S. Dalley, "Semiramis in History and Legend: A case study in interpretation of an Assyrian historical tradition, with observations on archetypes in ancient historiography, on euhemerism before Euhemerus, and on the so-called Greek ethnographic style" también se han ocupado de ellos.
} 
En todos estos materiales minorasiáticos los personajes están representados de pie, en actividad oficial, en una tensión activa, ejerciendo su función de fundadores de ciudades.

A la misma época que las monedas, a finales del siglo II o comienzos del III, corresponden unos materiales que fueron hallados bastante más al sur, en la provincia de Siria ${ }^{42}$. Se trata de unos mosaicos hallados en localidades muy próximas entre sí (Alejandretta-Iskenderum y Antioquía del Orontes-Dafne). En ambos se representa el mismo tema: Nino sentado contempla un retrato. En uno de los mosaicos aparece incluso el nombre "Nino" escrito sobre su cabeza. La escena podría encajar en el argumento de la obra, en algún episodio central que tuviera lugar cuando ya la pareja se hubiera separado.

\section{Interpretación de los textos}

Semíramis es el personaje eje de la historia asiria de Diodoro. Ella simboliza la idea antigua del carácter femenino de $\mathrm{Asia}^{43}$. Prueba elocuente del protagonismo de la reina asiria en el relato de Diodoro es el espacio que le dedica el autor: más del doble del dedicado al rey Nino, a quien Semíramis supera en todos los campos. En Diodoro, ella es la auténtica fundadora de Asiria. A pesar de su importancia, las empresas de Nino palidecen frente a la ambición, inteligencia y conquistas de su viuda. Semíramis es un personaje masculinizado, una especie de Amazona ${ }^{44}$, como aquellas que encontraremos después en sucesivos capítulos del libro de Diodoro ${ }^{45}$.

Volvamos ahora a un episodio que tiene lugar al principio del relato, cuando recién casada con su primer esposo diseña su propia vestimenta:

Como el asedio duraba ya mucho tiempo, el marido de Semíramis, que estaba locamente enamorado de su mujer y andaba de campaña militar con el rey, envió a por su esposa. Ella, a quien adornaban la sabiduría, la osadía y otras virtudes que confieren distinción, aprovechó la ocasión para demostrar, de nuevo, sus cualidades naturales. En primer lugar, como iba a hacer un viaje de muchos días, se confeccionó una prenda con la cual no se pudiera reconocer si quien la llevaba era un hombre o una mujer. Le resultaba cómoda para las travesías en días calurosos y para preservar el color de su cuerpo y le servía para poder hacer lo que quisiera: le permitiría moverse con facilidad y le daría un aspecto juvenil; por todo ello, estaba tan atractiva que, más tarde, los medos, cuando dominaron Asia, llevaban la prenda de Semiramis y los Persas también después ${ }^{46}$.

42 M. H. Quet, "Romans grecs, mosaïques romans", en M. F. Baslez, P. Hoffmann y M. Trédé (eds.), Le monde du roman grec, París 1992, pp. 125-58 ha estudiado y comentado los mosaicos.

43 M. G. Capomacchia, op.cit. y J. Lens Tuero y J. Campos Daroca, "La geografía de Asia en el libro II de la Biblioteca Histórica de Diodoro de Sicilia”, en Emerita 65.1, 1997, pp. 17-44.

44 Ya hemos comentado las noticias que vinculan a nuestra protagonista con la célebre amazona Pentesilea, en cuyo caso la masculinidad y agresividad propias de su carácter podrían ser herencia de su abuela paterna

45 Diodoro le dedica mucha atención a las Amazonas de Escitia en este mismo libro: II 44-46 pero también en el libro III a las de la Libia (a partir de III 52.1). Vid. S. Saïd, Le Monde à l'envers. Pouvoir feminine et communauté des femmes en Grèce ancienne, Les Belles Lettres, París 2013, pp. 121-158.

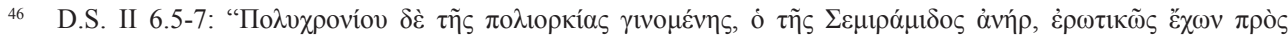

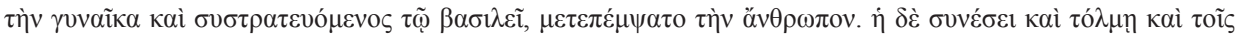




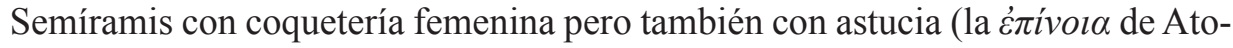
sa), se diseña ella misma una túnica, que oculta sus encantos y anula su femineidad. Este elemento, en mi opinión, opera como un resorte que nos desplaza a una nueva dimensión del relato ${ }^{47}$ : la metamorfosis, la masculinización de Semíramis ${ }^{48}$. A través del nuevo ropaje, la reina asiria adquiere un nuevo $\tilde{\eta} \theta$ oc.

La mujer, como el eunuco (en el relato de Diodoro, los eunucos tienen una gran presencia en estos reinos asiáticos ${ }^{49}$ ) y como el niño, es un hombre mutilado ${ }^{50}$. Las diferencias fisiológicas y anatómicas corren parejas a las diferencias psicológicas: Aristóteles opone el coraje viril dominante al coraje femenino subordinado, el hombre ha nacido para mandar y la mujer para ser mandada ${ }^{51}$.

En la versión de Diodoro, una vez investida con la túnica, Semíramis neutraliza su potente feminidad y se convertirá en un varón excepcional, en un ser superior, hasta el punto de poner en evidencia la inferioridad de sus parejas anteriores. La mujer que ha aparecido en escena casi como una anécdota acaba revelándose como la auténtica protagonista del relato, como en Parménides donde, al encuentro del joven auriga, aparece una diosa innominada, quien lo recibe amablemente y cuya voz se confundirá con la voz del autor a partir de ese momento. Como Diotima de Mantinea, maestra de Sócrates, muy presente en el Banquete, sin estarlo corporalmente. Tan explosivo es el potencial masculino de Semíramis que, a partir de ella, su hijo será un ser débil, afeminado. A partir de Semíramis, no hay vuelta atrás, su hijo Ninias inaugura una sucesión de reyes asirios que ya no serán dignos de mención ${ }^{52}$.

Hay versiones en las que Semíramis traspasa el marco sexual, se metamorfosea en algo asexuado, monstruoso, negativo y destructor, provocando la muerte involuntaria o voluntariamente a maridos-reyes y soldados-amantes. Su comportamiento erótico se ejerce contra natura: la pasión por el hijo y los sentimientos por su propio caballo ${ }^{53}$.

En la novela, el enfoque de la leyenda es distinto. Los personajes se han helenizado. Semíramis, cuyo nombre hay que tener en cuenta que ni siquiera aparece en los

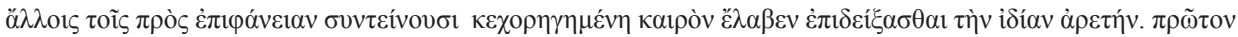

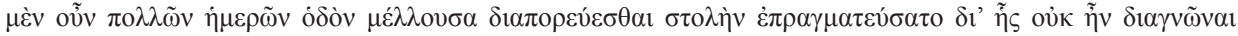

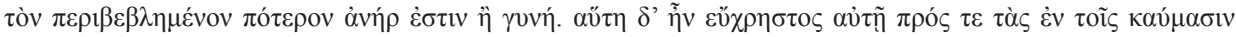

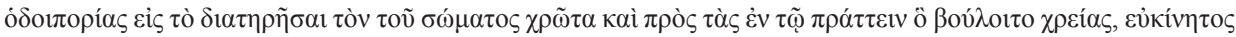

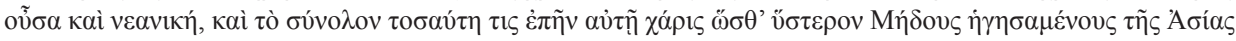

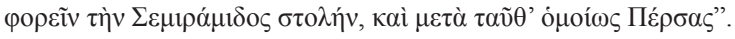

47 Según las teorías aristotélicas, nuestro carácter está condicionado por nuestra anatomía.

48 J. Lens Tuero y J. Campos Daroca, op.cit.: "Lo que distingue el Asia de Diodoro es que las mujeres toman el protagonismo de la acción, punto en el que ya encontramos importantes antecedentes en Heródoto. El tema del travestismo femenino, por el que las mujeres asumen con pleno éxito los roles viriles, es esencial en la tradición ctesiana, punto en el que es muy plausible que el modelo sea la literatura dramática". Pensamos que, efectivamente, la figura de la bárbara Medea, entre otros, debió de estar muy presente. Sobre la évó $\rho \gamma \varepsilon \imath \alpha$ de las heroínas dramáticas, vid. Demetr. Eloc. 208.

49 J. Lens-Tuero, J. García González y F. J. Campos Daroca, op. cit., pp. 295-298

50 S. Saïd, "La nature: féminine: La biologie d'Aristote", 2013, pp. 19-53 ha estudiado el concepto de "naturaleza femenina" en Aristóteles. Al coraje viril se opone el amor maternal: el heroísmo maternal. Aristóteles sí reconoce en este aspecto la superioridad de la mujer.

51 De ahí que las panteras, que tienen cuatro mamas, son más femeninas que otras hembras del reino animal. Vid. A., $H A$, II $1.500 \mathrm{a} 28$.

52 Ctesias conecta con una idea muy arraigada en la historiografía griega ya desde Heródoto -el escandaloso triángulo: esposa, Giges y Candaules-: la corrupción y el desenfreno sexual en las cortes orientales. Vid. G. B. Lanfranchi op.cit., p. 218. El nivel más bajo de esta decadencia se sitúa en Sardanápalo, el más afeminado de todos los reyes persas.

53 M. G. Capomacchia, op.cit., p. 60. 
fragmentos conservados, se oculta en el anonimato y en la discreción que se espera de la mujer griega. Semíramis ya no es Semíramis, se alude a ella como $\dot{\eta} \pi \alpha \tilde{i} c, \dot{\eta}$

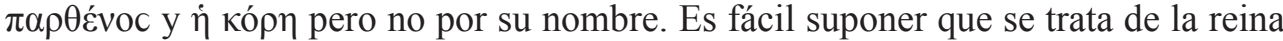
asiria porque en los textos conservados del papiro sí se menciona el nombre de su madre, Dercia, que es una adaptación evidente del nombre de la madre legendaria de Semíramis, Derceto de Ascalón.

La reina asiria, cuya personalidad se presenta arrolladora en la mayoría de las fuentes griegas ${ }^{54}$, no se puede reconocer con facilidad en el texto de estos papiros. Su cuerpo ha quedado paralizado a causa de la emoción y de la vergüenza y ella es incapaz de actuar, sólo de sentir ${ }^{55}$.

El joven príncipe, sin embargo, es un hombre de acción, cuyos sentimientos se traducen en una mayor capacidad y agresividad, no sólo bélica, sino también retórica, que ya hemos comentado ${ }^{56}$. Armenia es su primera batalla decisiva; vencidas las inclemencias del tiempo y la dureza del terreno, Nino acampa en una llanura y planifica meticulosamente el orden de batalla: dentro la infantería, protegida a los lados por la caballería y los gimnetas. En la vanguardia, ciento cincuenta elefantes en formación de torre y el propio Nino, cabalgando al frente de todos. Antes de pasar a la acción, alza las manos y pronuncia una arenga para motivar a las tropas ${ }^{57}$, la actitud en la que se representa al propio Augusto, en la estatua hallada en Prima Porta que el Senado le dedicó ${ }^{58}$.

Aunque la Ciropedia, ambientada en Persia, es uno de sus modelos fundamentales, la educación que recibe el protagonista de esta novela es la $\pi \alpha 1 \delta \varepsilon i ́ \alpha$ griega: Nino es un $\pi \varepsilon \pi \alpha 1 \delta \varepsilon v \mu \varepsilon ́ v o c$, un joven completamente helenizado, que, en el brillante discurso que pronuncia ante su tía Dercia para pedirle la mano de su prometida ${ }^{59}$, maneja con soltura conceptos y términos retóricos, filosóficos y jurídicos ${ }^{60}$.

Frente a la $\pi \alpha \rho \rho \eta c i ́ \alpha$ de la que disfruta Nino (evidentemente, una palabra con claras connotaciones políticas $)^{61}$, su prima no goza de este mismo derecho: incapaz de hablar, sólo se expresa mediante el lenguaje corporal: se ruboriza o palidece, llora y

54 Recordemos que el P. Oxy. 2564 publicado en 2016 contiene un que menciona la conquista de Egipto y la construcción de pirámides por parte de una reina que podría ser Semíramis, aunque no se pueden descartar otras posibilidades como una amazona -por ejemplo, Mirin-, una persa - quizás Atosa-, o una etíope como podría ser Candace, aunque a nosotros la reina asiria nos parece la opción más probable. Cf. p.4, n. 21 y M. P. López-Martínez, "La acción novelada de la reina Semíramis", en C. Martínez y P. Ubric (eds.), Cartografias de Género en las Ciudades Antiguas: Memorias y Poder de las Mujeres, Universidad de Granada (volumen en preparación).

55 M. P. López-Martínez, "La paideia del príncipe Nino", en A. López Eire, J. M. Labiano Ilundain y A. Seoane Pardo (eds.), Retórica, Política e Ideología desde la Antigüedad hasta nuestros días. Actas del II Congreso Internacional. Salamanca, noviembre 1997, vol. I, Logo. Asociación Española de Estudios sobre Lengua, Pensamiento y Cultura Clásica, Salamanca 1998, pp. 51-56 y "New contributions to some papyri labelled as «incerta» in a corpus of novel fragments", en G. Bastianini y A. Casanova, I papiri del romanzo antico. Convegno internazionale di studi, -Istituto Papirologico G.Vitelli, Istituto Papirologico G. Vitelli, Florencia 2010, pp. 95-119.

$56 \quad$ Ibidem, pp. 7-8, n. 39.

57 El vocabulario y el estilo del episodio remiten a la historiografía griega: Tucídides, Jenofonte (Ciropedia) y Polibio. Para las referencias literarias, remitimos a Kussl, Papyrusfragmente griechischer Romane. Ausgewählte Untersuchungen, pp. 34-63 y "Ninos-Roman".

58 M. P. López-Martínez, "The Ninus novel: text and context” (en preparación).

59 Reproducido aquí en pp. 7-8 y n. 39.

60 M. P. López-Martínez, "La paideia del príncipe Nino" y "New contributions to some papyri labelled as «incerta» in a corpus of novel fragments".

61 Término empleado por el autor de la novela y traducido por "libertad de palabra", cf. p. 8 y n. 40. 
es incapaz de mirar a los ojos de su tía. Aquí la referencia es claramente Safo. Lo que en Nino se entendería como un defecto en su prima se interpreta como una virtud ${ }^{62}$; la perspectiva de género como explicación a estas diferencias resulta inevitable.

Partiendo de los testimonios historiográficos, parece claro que los personajes novelescos se han reinventado atendiendo al canon de la pareja heterosexual propio del género literario que fue el último en nacer en Grecia y que está representado por la prosa de ficción. Dicho canon, indudablemente se ve reforzado por una antigua y rica tradición de misoginia griega ${ }^{63}$.

Mi opinión es que el patrón heterosexual de la pareja así formada por Nino y Semíramis se propone como el modelo en el que se deben reflejar los jóvenes lectores que se sitúan en una franja de edad similar a la de los protagonistas de esta novela o a la de aquéllos que tienen en sus manos la responsabilidad de su educación. Además, en un futuro no muy lejano, será útil que estos adolescentes se conviertan en padres y madres de familia. En esta misma línea, también Dalley planteó la posibilidad de que la novela de Nino se utilizara con la finalidad de promover el acto heterosexual:

I was reminded of a city ordinance passed in Venice in the late fifteenth century, where homosexual acts became so prevalent that prostitutes were ordered to walk bare-breasted, in the hope of discouraging homosexual acts. Rulers who go to war need and endless supply of young men, and only heterosexual relationships produce them ${ }^{64}$

y con anterioridad también Morales planteó esta misma finalidad con respecto al género de la novela griega ${ }^{65}$.

\section{La interpretación de las imágenes}

Los materiales de Lidia y Caria manifiestan la intención de trasladar a las épocas más remotas, a un espacio temporal que se encuentra en la frontera entre el mito y la historia, el origen de una serie de ciudades que carecen de nobles ancestros. Al político, en el caso de Afrodisias, se podría añadir un interés económico: justificar el trato pri-

62 Cf. M. P. López-Martínez, "La paideia del príncipe Nino" y "New contributions to some papyri labelled as «incerta» in a corpus of novel fragments" y M. Anderson, "The Silence of Semiramis: Shame and Desire in the Ninus Romance and Other Greek Novels", en AN 7, 2009, pp. 1-27. P. Liviabella Furiani, "Il corpo nel romanzo di Achille Tazio", Ancient Narrative 1(2000-2001), pp. 134-151 ofrece un estudio sobre el cuerpo en la novela de Aquiles Tacio. J. König, "Body and Text", en T. Whitmarsh (ed.), The Cambridge Companion to the Greek Novel, Cambridge University Press, Cambridge 2008, pp. 127-144 presenta un estudio de carácter más general.

63 Vid. M. Jufressa (ed.), Saviesa i perversitat: les dones a la Grècia Antiga, Destino, Barcelona 1994, por citar sólo un título entre la abundante bibliografía existente. En general, sobre el tema de la sexualidad y la literatura erótica grecolatina, remitimos a la página personal de Juan Francisco Martos Montiel de la Universidad de Málaga: http://webpersonal.uma.es/ jfmartos/BEGLintro.htm (fecha de la consulta: 8-XII-2015).

64 S. Dalley, "The Greek Novel 'Ninus and Semiramis", op. cit., p. 126.

65 H. Morales, "The History of Sexuality", en T. Whitmarsh (ed.), op. cit., pp. 39-55 se hace eco del debate que se abrió a partir de la publicación de la obra de Michel Foucault (Poitiers 1926-París 1984) respecto al papel que la novela habría desempeñado en la historia de la sexualidad, así como sobre la posibilidad de concebir el género como una celebración de la heterosexualidad. En cualquier caso, es sabido que la lectura de los Relatos babilonios de Jámblico, una novela también perdida de la que no conservamos papiros, pero sí el resumen de Focio, era recomendada por los médicos como antídoto contra la impotencia. 
vilegiado que esta ciudad recibe de Roma. En la región de Siria, por el contrario, la perspectiva desde la que se enfoca la leyenda de Nino y Semíramis es diferente. He de reconocer que, de momento, no estoy en condiciones de apuntar una justificación para este diferente tratamiento. En Afrodisias, Aninetta y Thyatira (tanto en los relieves de la Basílica como en las monedas) los personajes se presentan en su dimensión pública, oficial. Sin embargo, en los mosaicos de Antioquía y Alejandretta, que se encuentran, por cierto, en casas particulares, se hace un uso privado de este motivo: Nino, en Siria, aparece en una escena íntima, disfrutando del otium. Cómodamente sentado adopta una actitud melancólica, mientras sostiene en la mano el retrato de su amada. El nombre de Semíramis no aparece en los fragmentos y es muy probable que tampoco esté presente físicamente en la escena del mosaico, aunque quizás la amada de Nino sí aparecería retratada en el interior del marco que Nino sostiene en la mano ${ }^{66}$.

Además, precisamente, muy cerca de Antioquía y Alejandretta, en la misma región y por las mismas fechas, Luciano de Samósata (125-190 d.C.) alude a actuaciones pantomímicas en los teatros protagonizadas por Nino, junto a Metíoco y Aquiles. Estas piezas son un testimonio más del uso artístico (en principio, no propagandístico, ni político) de la leyenda de Nino en la región ${ }^{67}$.

\section{Conclusiones}

En mi opinión, al carácter patriótico de los textos que conservamos de la novela de $\mathrm{Nino}^{68}$, se añade un propósito pedagógico más o menos consciente por parte del autor: la educación sentimental y sexual de los sectores más jóvenes de una sociedad especialmente compleja.

La novela de Nino se presta a una lectura en clave sociológica y pone el foco en un aspecto crucial de los periodos helenístico e imperial: el conflicto interno que probablemente experimentarían los habitantes de los territorios periféricos. Se trataba de una población que había sido educada en el paradigma de la cultura griega y cuya lengua materna era el griego. En especial, me refiero a la elite de los $\pi \varepsilon \pi \alpha \imath \delta \varepsilon v \mu \varepsilon ́ v o l$, a la gente culta que llevaba una existencia civilizada -tal como ellos la debieron de entender- en tierras que proverbialmente habían sido consideradas de bárbaros. Son tierras colindantes con los extremos de Asia $^{69}$, el espacio donde se producían las aberraciones que aparecen de manera recurrente en el imaginario de muchos de los mitos griegos.

66 Creemos que la mujer que aparece en uno de los mosaicos podría ser una sirvienta que le acerca una lámpara para contemplar mejor dicho retrato, aunque no se pueden descartar completamente otras posibilidades: la mujer a la que ha liberado antes de llegar a la Cólquide, la propia joven, su madre, etc.

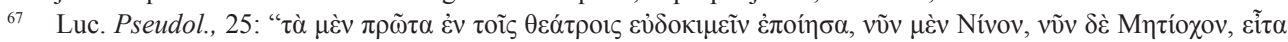

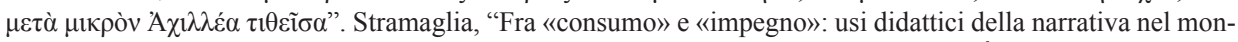
do antico", pp. 97-166 y C. Ruiz-Montero, "Novela y pantomimo: vidas paralelas”, en Á. Martínez-Fernández (coord.), Agalma: ofrenda desde la Filología clásica a la Manuel García Teijeiro, Universidad de Valladolid, Valladolid 2014, pp. 609-621.

68 Los papiros que conocemos como novela de Nino, los ya citados P. Berol. $6926+$ P. Gen. 85 y PSI 1305.

69 Un ejemplo especialmente interesante de lo que decimos es el sitio arqueológico de Ai-Khanoum, en las orillas del río Oxo, en Afganistán. Allí se encontró una magnífica ciudad de fundación helenística con infraestructuras y edificaciones importantes, entre ellas, una biblioteca donde se han conservado papiros literarios. 
En síntesis, nuestra propuesta se articula en los siguientes puntos:

1. Los testimonios que hacen referencia a las figuras de Nino y Semíramis son los siguientes:

A) El rey asirio Tukultī-Ninurta I (1243-1207). Se trata de una hipótesis muy plausible, aunque en las tablillas acadias no se produce dicha identificación. Speiser 1958 defendió con argumentos lingüísticos la tesis de que "Nívoc" pueda ser la forma helenizada de "Tukultī-Ninurta", como

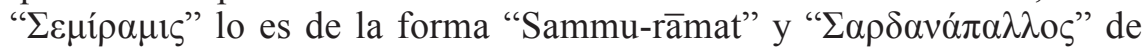
"Asurbanipal".

La reina asiria Sammu-rāmat, esposa de Samsi-adad V, que tuvo que asumir la regencia de Asiria en torno al 810 a.C.

B) Tukultī-Ninurta I (Nino, de ser válida la hipótesis de identificación del punto anterior) en las tablillas acadias es el protagonista del poema $L a$ gesta de Tukulti-Ninurta, un poema de corte escrito en vida del rey para celebrar su victoria sobre el rey de Babilonia. Sammu-rāmat aparece probablemente citada en inscripciones.

C) Siglo V-IV a.C.: Heródoto ${ }^{70}$ cita a Nino en calidad de fundador de la ciudad de Nínive. También es uno de los protagonistas de los relatos asirios de Ctesias, junto con su esposa Semíramis. A partir de estas fuentes, la leyenda se recoge en otros autores griegos.

D) Siglo I a.C.: Diodoro Sículo incorpora la leyenda de Nino y Semíramis en su proyecto de historia universal, convirtiendo a Nino en el primer rey asirio nativo del que se conserva memoria aunque, en realidad, es Semíramis la verdadera protagonista del relato.

E) Siglo I a.C.: Un novelista anónimo reinterpreta la leyenda, devolviendo a Nino el protagonismo de la historia. Los papiros que conservan textos de esta novela perdida se han hallado en Egipto y están fechados entre el siglo I a.C. y I d.C.

F) En el siglo I d.C. se representan las figuras de Nino y Semíramis en relieves de la basílica de Afrodisias (Asia Menor) ya como fundadores de la ciudad.

G) A mediados del II d.C., Luciano de Samósata (Siria) nos informa de que Nino es un personaje en las representaciones de pantomimo.

H) En el siglo II y III d.C. encontramos a Nino y Semíramis en monedas acuñadas en Aninetta y Thyatira (Asia Menor) como fundadores de dichas ciudades.

I) También a finales del siglo II-III d.C. corresponden los mosaicos de la casa de un hombre ilustrado de Alejandreta o Dafne con la figura de Nino sentado y contemplando un retrato de mujer.

J) Un papiro fechado a finales del siglo II d.C. o comienzos del III d.C. y hallado en Egipto podría ser el único testimonio hasta hoy de una novela de Semíramis también perdida, protagonizada por la reina asiria.

2. La leyenda de Nino contribuyó a afianzar la identidad común de las élites locales tanto en la región de minorasiática como en la provincia de Siria. 
3. Por lo que respecta a la cultura material, dicha la leyenda adoptó un carácter distinto dependiendo de la zona: oficial y político, en Asia Menor; íntimo y lúdico, en Siria. Por el momento, no estoy en condiciones de sugerir la razón de esta diferencia.

4. Dos textos literarios prácticamente contemporáneos entre sí evidencian dos versiones muy distintas de esta leyenda. La versión de Diodoro, historiográfica y de origen occidental, refleja la imagen tradicional del Asia femenina, con patrones invertidos y en la que una mujer como Semíramis encarna valores masculinos. Frente a la versión historiográfica, la novelesca de origen oriental heleniza a estos personajes: el varón manda, porque ha nacido para mandar, y la mujer es sumisa, porque ha nacido para obedecer.

5. Mi opinión con respecto al posible origen y autoría de la novela de Nino se articula en dos hipótesis

5. A. Un candidato para ser considerado el autor del texto podría ser Nicolás Damasceno o alguien de su origen y perfil intelectual y profesional. Nicolás nació en Damasco, el año 64 a.C., en el seno de una familia influyente y helenizada. Recibió una educación a la griega, enciclopédica, estudiando retórica, música, ciencias y filosofía. A partir del 14 a.C., ejerció como secretario, vं de confianza y como tutor de sus hijos. Es autor de una Historia Universal ${ }^{72}$.

5. B. La segunda hipótesis contempla el origen parto de esta novela ${ }^{73}$ y se basa en los siguientes argumentos ${ }^{74}$ :

5.B.1: Mitrídates I de Partia, en el año 141 a.C. estableció la dinastía Arsácida, un estado multiétnico, cuyo centro se encontraba en la ciudad de Seleucia en el Tigris. El propio Mitrídates se autodenominó filoheleno y acuñó monedas en griego ${ }^{75}$. Los partos hablaban griego y fueron en general tolerantes con los demás pueblos, pero muy especialmente con los griegos, de cuya cultura se impregnaron completamente.

5.B.2: En mi opinión, algún autor de origen parto (evidentemente grecoparlante), o de origen griego, pero con estrechos vínculos en Partia y con un alto nivel de la cultura literaria griega, podría haber escrito la novela de Nino. Tanto el propio novelista anónimo como sus lectores se identificarían fácilmente con el pro-

71 La misma profesión que el autor de Quéreas y Calírroe, la primera novela griega conservada completa según revela él mismo en las primeras líneas de su obra.

72 E. Parmentier y F. P. Barone, Nicolas de Damas. Histoires. Recuelil de coutumes. Vie d'Auguste. Autobiographie, Les Belles Lettres, París 2011, pp. XI-XX.

73 En contra de lo que sostienen Tilg, op. cit. y otros quienes, como ya hemos comentado, consideran Afrodisias y concretamente el período que abarca los años 66-68 d.C., respectivamente, como la ciudad de origen de la novela y la fecha de composición de esta.

74 En M. P. López-Martínez, "The Ninus novel: text and context” (en preparación) desarrollo con más detenimiento esta afirmación.

75 Sobre la cuestión del filohelenismo de los partos: J. Wolski, "Sur le «phihellénisme» des arsacides", en Gerión,1, 1983, pp. 147-156. 
tagonista del relato: un rey autóctono, nacido en el corazón de Mesopotamia, entre el Tigris y el Éufrates, pero con formación y costumbres griegas.

5.B.3: Sabemos que existió un corpus de leyendas partas, que resulta en la actualidad difícil de conocer por su carácter fundamentalmente oral. Nos consta que, en la transmisión de dicho patrimonio, desempeñaban un importante papel los juglares, gosan. Conocemos muy poco de dicho corpus, que debió de ser muy rico y del que sólo una parte ha llegado a nosotros gracias a versiones en persa del período pre-islámico. Uno, uno de los títulos más importantes de esta literatura fue el Libro de los reyes (Shahnameh) de Firdusi:

Thus, a fragment of the Kayanian epic cycle survives in the Ayādgār 1 Zarērān (q.v.) or "Memorial of Zarēr" This heroic poem, transmitted in a late post-Sasanian Middle Persian redaction (perhaps of the 9th century), is undoubtedly of Parthian origin, as can be seen from the use of Parthian words and expressions. It relates the exploits of the Iranian hero Zarēr in the confrontation of the Iranians under King Wištāsp with King Arjāsp and his Xiyonians. A number of passages were later taken over almost word for word in the Šāh-nāma. Another work of Parthian origin that has come down to us in a Persian version of the 11th century and a Georgian version of the 13th century is the romance of Vis o Rāmin, which relates the story of Rāmin's love for the wife of his brother, King Mōbad. Finally, wisdom literature is represented by the Draxt $\overline{1}$ asūrīg (q.v.) or "The Babylonian Tree" another Middle Persian poem of Parthian origin, in which the contest between a palm tree and a goat may be interpreted as an allegory on the superiority of pastoral life over agriculture ${ }^{76}$.

5.B.4: Contamos con traducciones de novelas griegas al persa, al árabe, al copto y/o a otras lenguas orientales, tanto en prosa como en verso $^{77}$. El ejemplo más rico es la Vida de Alejandro, de la que se conservan versiones en varias lenguas orientales. Asimsimo, contamos con la traducción al persa de una novela griega perdida, de cuyo original nos han llegado tan solo fragmentos de papiro hallados en Egipto: se trata de la novela de Parténope. Es también una novela de tema histórico ${ }^{78}$. Aunque de la novela de Nino no conocemos ningún testimonio en persa, me parece

76 Ph. Huyse, en Encyclopaedia Iranica, vol. XIII, Fasc. 4, pp. 410-414, versión on-line: http://www.iranicaonline. org/articles/iran-viii1-persian-literature-pre-islamic\#i (fecha de la consulta 10-XII-2015).

77 Algunas recogidas en el estudio de D. Davis, Panthea's Children: Hellenistic Novels and Medieval Persian Romances, Bibliotheca Persica Press, Nueva York, 2002.

78 El más reciente estudio de conjunto sobre la totalidad de los testimonios de esta novela griega perdida es el libro 
verosímil plantear su existencia.

5.B.5: Durante el siglo I a.C. los partos defendieron celosamente un territorio que los romanos de ninguna manera conseguían conquistar. En este contexto, se explicaría la intención propagandística de la escritura de la novela de $\mathrm{Nino}^{79}$. Esta intención propagandística, patriótica ${ }^{80}$, se sospecha también de otras novelas como la Vida de Alejandro o la novela de Sesoncosis, inspirada en el faraón egipcio Sesostris, también perdida y de la que se conservan varios papiros. En el caso del asirio Nino, se trata de un personaje nativo que reivindica el pasado legendario de su pueblo. Al ser un líder autóctono, su autoridad sobre el territorio es legítima. Nino encarna las virtudes de los aquellos grandes líderes de pueblos orientales pero, al mismo tiempo, la educación y los ideales griegos. Semíramis se adapta, por su parte, al estereotipo de discreta y sumisa esposa griega.

6. Con respecto a la fecha de composición de la novela: En el siglo I a.C. se produce un episodio crucial que podría entenderse como el terminus post quem para la escritura de la novela.

6.1:el año 53 a.C., fecha en la que tiene lugar la famosa batalla de Carras. Craso había roto el acuerdo adoptado entre romanos y partos por el cual el río Éufrates se convertía en la frontera entre dos estados. El rey armenio Artavasdes II ofreció ayuda a Craso de cara a esta batalla. Los partos humillaron a los romanos, que eran más numerosos y estaban mejor equipados.

6.2: Como castigo por la ayuda prestada a los romanos, el rey parto Orodes II invadió Armenia. Este ataque parto contra Armenia podría haber inspirado el episodio novelesco de la batalla de Nino contra Armenia descrito en la columna B del papiro de Berlín.

6.3:En el año 20 a.C., el Senado dedicó a Augusto una estatua de mármol. Dejando a un lado la polémica con respecto a la fecha y al significado de esta pieza, podemos decir que, en el relieve de la coraza, se representa a un rey parto sometido, devolviendo el estandarte de Craso a un romano armado. La escena nos invita a preguntarnos si el sentimiento de triunfalismo romano que inspiró la creación de esta estatua - con un acentuado carácter propagandístico también- podría ser compatible con una situación en la que los sentimientos patrióticos de los partos estuvieran tan exaltados como para animar a un autor a componer un relato sobre un líder vencedor. Quizás, sí, pero, de ser negativa la respuesta, la novela podría haberse escrito antes del 20 a.C., fecha de la estatua y que podría entenderse como un terminus ante quem con respecto a la escritura de la novela.

de T. Hägg y B. Utas, The Virgin and her lover. Fragments of an Ancient Greek Novel and a Persian Epic Poem, Brill, Leiden-Boston 2003.

79 Hemos hecho referencia también a cierta intención pedagógica por parte del autor -cf. pp. 12-13-, que es compatible con la intención patriótica de la que hablamos ahora.

80 El precursor de la teoría fue el trabajo de Braun citado en p. 4, n. 22. 
7. Los protagonistas de nuestra novela, el rey asirio Nino y su prima -entendiendo que el personaje anónimo femenino remite necesariamente a la Semíramis - cobran vida, cuerpo, de acuerdo con unos intereses patrióticos que tendrían justificación en la región de Partia durante la segunda mitad siglo I a.C. Este sería el contexto de la creación de este texto novelesco.

8. La novela de Nino refleja los ideales de femineidad y masculinidad propios de la $\pi \alpha \_\delta \varepsilon i ́ \alpha$ griega tradicional. En una época de globalización y en una región de la periferia, es fácil imaginarse a sus lectores completamente helenizados y profundamente orgullosos tanto de sus orígenes como de la educación recibida. 